\title{
PENGARUH MEDIA VIDEO TENTANG PARIWISATA DI KABUPATEN PESAWARAN TERHADAP PENINGKATAN PENGETAHUAN MAHASISWA
}

\author{
Anna Gustina Zainal \\ Program Studi Ilmu Komunikasi, Fisip Universitas Lampung \\ Email: annarudi76@gmail.com
}

\begin{abstract}
This study uses realistic visualization in the form of photos which are the result of photographic elements, as well as visualization with infographic forms which are illustrative elements in visual communication design. the research uses True Experimental method with 2x2 factorial design and uses Pretest, Posttest, and Control Group Design. The purpose of this study is to examine the effect of visual presentation and language style through video media for increasing student knowledge and analyzing the most effective combination of messages on video media about tourism in Pesawaran District. From this research it is found that visual presentation and language style through video may influence improvement of student knowledge about tourism in Pesawaran Regency. All combinations of visual presentation and language style will influence knowledge improvement.
\end{abstract}

Keywords: Video Media, Tourism, Pesawaran Regency

\section{Pendahuluan}

Pesawaran merupakan salah satu kabupaten di Lampung yang memiliki daerah wisata unggulan berupa keindahan laut dan pulau kecil yang mengitarinya. Atraksi wisata yang dimiliki kabupaten Pesawaran sangat diminati oleh para wisatawan, baik nusantara maupun wisatawan mancanegara. Hal itu terbukti dari jumlah kunjungan wisatawan yang dari tahun ke tahunnya mengalami peningkatan. Tahun 2014 tercatat sekitar 1.096.366 wisatawan nusantara maupun wisatawan mancanegara yang melakukan kunjungan di obyek pariwisata Pesawaran, dan pada tahun 2015 peningkatan cukup besar yaitu mencapai 1.588 .615 kunjungan (Disparbud Kabupaten Pesawaran 2015). 
Pada penelitian ini digunakan visualisasi realistik berupa foto yang merupakan hasil dari elemen fotografi, serta visualisasi dengan bentuk infografis yang merupakan elemen ilustrasi dalam desain komunikasi visual. Berdasarkan penelitian Gustina (2013) menjelaskan bahwa penggunaan visual realistik lebih efektif daripada visual grafis untuk meningkatkan pengetahuan responden. Media video merupakan salah satu media yang sangat efektif dan persuatif (Kamlongera \& Mefalopulos 2014). Penggunaan video sangat efektif dalam meningkatkan pengetahuan (Gustina, 2013). Media video yang menggunakan audio dan visual memiliki keunggulan dibandingkan dengan media lainnya. Keunggulan video ini dapat mengkombinasikan teks, grafik, suara, dan visualisasi (Nurfathiyah \& Suratno 2011). Pada media audiovisual biasanya dikenal dua jenis visualisasi, yaitu visualisasi realistik dan visual grafis.

Komunikasi tidak lepas dari penggunaan bahasa, penggunaan bahasa ini digunakan dalam menyampaikan pesan untuk menunjang efektivitas komunikasi (Gustina, 2013). Bahasa ini digunakan dalam pariwisata untuk meningkatkan elemen persuasi dan daya tarik dari berbagai macam media (Salim et al. 2012 dalam Gustina, 2013). Gaya bahasa berdasarkan pemilihan kata terdiri dari gaya bahasa resmi, gaya bahasa tidak resmi, dan percakapan. Gaya bahasa yang digunakan dalam penelitian ini adalah gaya bahasa resmi dan percakapan. Media sosial merupakan salah satu kemajuan teknologi yang dapat membuat orang merasa tidak ada jarak dan waktu. Hal tersebut merupakan cara baru seseorang terhubung secara sosial dengan mengintegrasikan informasi dan teknologi komunikasi, interaksi sosial, konstruksi kata-kata, gambar, video, dan audio (Zeng \& Gerritsen dalam Mefalopulos P. 2014).

Media sosial ini dapat digunakan untuk mempromosikan suatu obyek wisata dalam usaha meningkatkan daya saingnya. Media sosial adalah mekanisme yang paling cepat dalam mempromosikan produk baru, layanan, dan industri pariwisata yang baru hadir (Bizirgianni \& Dionysopoulou 2013). Media video melalui media 
sosial yang berisi mengenai informasi yang menunjang diharapkan dapat memenuhi kebutuhan wisatawan akan informasi mengenai suatu destinasi pariwisata, seperti memberikan gambaran dan pengetahuan tentang obyek wisata, serta meyakinkan calon wisatawan muda untuk berkunjung ke obyek wisata yang ditawarkan.

Tujuan penelitian adalah untuk (1) menguji pengaruh penyajian visual dan gaya bahasa melalui media video terhadap peningkatan pengetahuan mahasiswa, (2) menganalisis kombinasi pesan yang paling efektif pada media video tentang pariwisata di Kabupaten Pesawaran.

Pada penelitian ini, media video digunakan dalam upaya mempromosikan pariwisata. Subyek penelitian diberikan perlakuan berbeda dalam penerimaan video, yaitu melalui penyajian visual $\left(X_{1}\right)$ dan gaya bahasa $\left(X_{2}\right)$. Penyajian visual dan gaya bahasa ini merupakan variabel bebas aktif. Penyajian visual dibedakan menjadi foto dan infografis, sedangkan gaya bahasa dibedakan menjadi gaya bahasa resmi dan gaya bahasa percakapan. Video ini diduga dapat meningkatkan pengetahuan subyek penelitian (Y) yang merupakan variabel terikat. Kerangka pemikiran tersebut dapat tergambar pada Gambar 1 berikut ini.

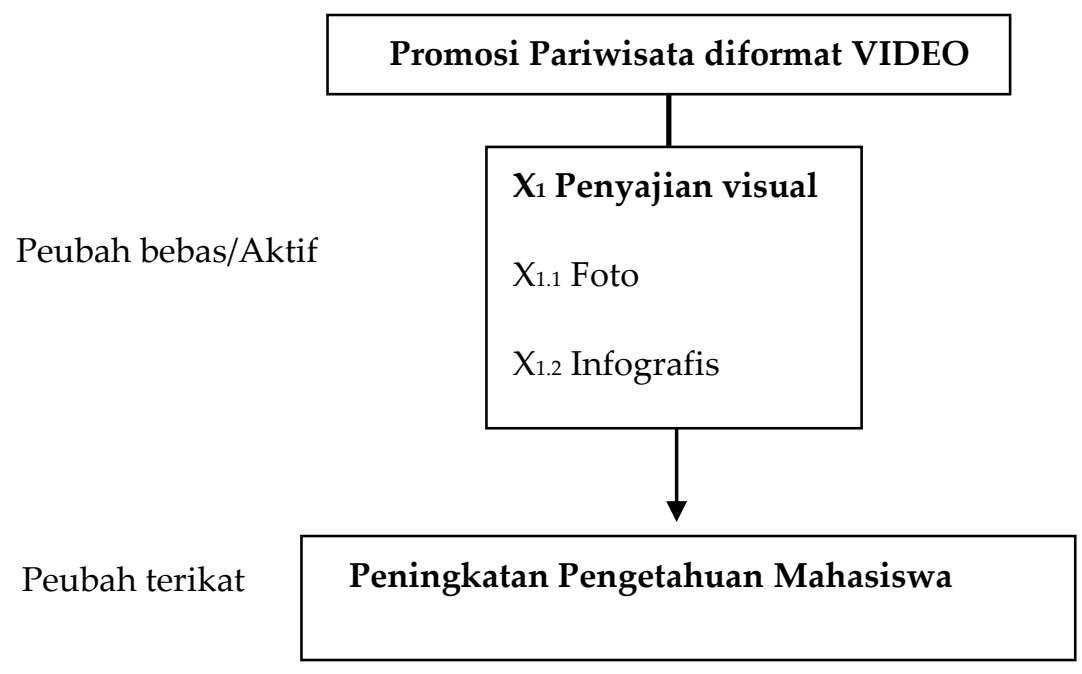

Gambar 1. Kerangka pemikiran pengaruh penyajian visual dan gaya bahasa pada video tentang pariwisata di Pesawaran terhadap peningkatan pengetahuan Mahasiswa. 
Berdasarkan kerangka pemikiran tersebut, hipotesis penelitian ini yaitu 1) terdapat pengaruh nyata pada penyajian visual dan gaya bahasa melalui video terhadap peningkatan pengetahuan, dan 2) terdapat perbedaan nyata antara kombinasi perlakuan dalam peningkatan pengetahuan.

\section{Metode Penelitian}

Lokasi penelitian di Universitas Lampung, Jl. Sumantri Brojonegoro Bandar Lampung. Waktu penelitian dimulai pada bulan Mei 2016. Penelitian ini merupakan penelitian eksperimental murni (true experiment) dengan desain faktorial $2 \times 2$ menggunakan pretest posttest control group design (Campbell \& Stanley 1996). Penyajian visual terdiri dari foto dan infografis, sedangkan gaya bahasa terdiri dari gaya bahasa resmi dan percakapan, sehingga didapatkan empat kombinasi perlakuan.

Subyek penelitian adalah mahasiswa dengan kisaran umur 19 sampai 21 tahun di program studi Jurusan Ilmu Komunikasi. Subyek penelitian dipilih secara acak sebanyak 75 orang, yang kemudian dibagi dalam empat kelompok eksperimen dan satu kelompok kontrol. Evaluasi media menggunakan metode face validity dan in house, serta metode open house. Validitas instrumen menggunakan analisis statistik product moment pearson dan pertanyaan yang valid menggunakan analisis ini sebanyak 23 items. Reliabilitas menggunakan cronbanch's alpha dengan nilai koefisien 0.796, dengan kata lain instrumentasi yang digunakan sudah reliabel. Analisis data dilakukan dengan menggunakan 1) analisis deskriptif untuk menggambarkan profil responden; 2) menguji skor pretest dan posttest dianalisis dengan uji $t$ dua sampel berpasangan (paired sample t-test); 3) mengkaji perbedaan peningkatan pengetahuan responden menggunakan analysis of varians; dan 4) menguji nilai tengah mana saja yang sama dan mana yang tidak sama di antara nilai-nilai tengah peningkatan pengetahuan responden, dilakukan uji wilayah berganda Duncan (Duncan's multiple range test). 


\section{HASIL DAN PEMBAHASAN}

\section{Profil Responden}

Jenis Kelamin

Profil mahasiswa pada penelitian ini terdiri dari indikator jenis kelamin, maksud berpergian, dan keterdedahan media komunikasi. Responden dalam penelitian dipilih secara purposive, yaitu mahasiswa yang berumur 19-21 tahun (mahasiswa tingkat tiga) dari mahasiswa Universitas Lampung. Responden dalam penelitian ini, seluruhnya berjumlah 75 orang mahasiswa yang terdiri dari 24 mahasiswa laki-laki dan 51 mahasiswi perempuan, hal itu dapat dilihat pada Gambar 2.

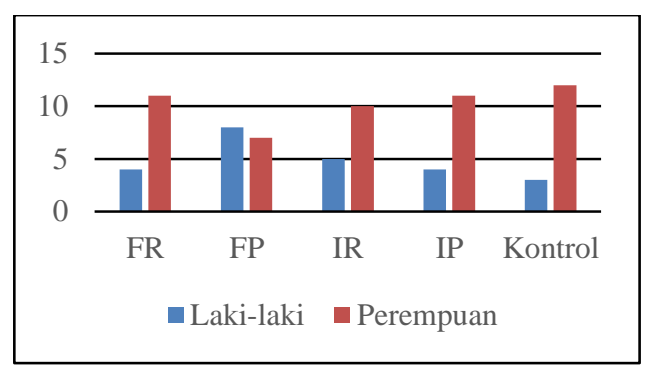

Gambar 2 Diagram sebaran jenis kelamin Sumber: Hasil olahan data peneliti (2019)

Keterangan: FR (Foto - Bahasa Resmi)

FP (Foto - Bahasa Percakapan)

IR (Infografis - Bahasa Resmi)

IP (Infografis - Bahasa Percakapan)

Kontrol (Kelompok Kontrol)

Pada Gambar 2 dapat dilihat bahwa kelompok dengan perlakuan foto dan gaya bahasa resmi (FR) terdiri dari empat orang laki-laki dan 11 orang perempuan, kelompok dengan perlakuan foto dan gaya bahasa percakapan (FP) terdiri dari delapan orang laki-laki dan tujuh orang perempuan, kelompok dengan perlakuan infografis dan gaya bahasa resmi (IR) terdiri dari lima orang laki-laki dan 10 orang perempuan, kelompok dengan perlakuan infografis dengan gaya bahasa percakapan 
(IP) terdiri dari empat orang laki-laki dan 11 orang perempuan, sedangkan kelompok kontrol terdiri dari tiga orang laki-laki, 12 orang perempuan.

\section{Maksud Berpergian}

Maksud berpergian ini terdiri dari empat parameter yaitu tujuan melakukan perjalanan pariwisata untuk rekreasi santai, pariwisata sejarah dan budaya, pariwisata agama, pariwisata sport. Maksud berpergian responden dapat dilihat pada Tabel 1. Maksud berpergian mahasiswa mayoritas memiliki maksud berpergian dengan tingkat sedang yaitu sebesar 62.67 persen, kemudian diikuti maksud berpergian dengan tingkat rendah yaitu sebesar 25.33 persen, dan terakhir maksud berpergian dengan tinggi yaitu sebesar 12.00 persen. Pemilihan maksud berpergian yang paling tinggi nilainya yaitu untuk pariwisata rekreasi santai, diikuti oleh pariwisata sport, pariwisata sejarah dan budaya, dan yang paling rendah untuk maksud berpergian pariwisata agama. Dari keseluruhan responden, terdapat tujuh orang yang pernah mengunjungi pariwisata di daerah Pesawaran, kedua di antaranya memiliki peningkatan pengetahuan yang tinggi, sedangkan yang lainnya memiliki peningkatan pengetahuan yang sedang. Selain itu, dari ketujuh responden ini dua di antaranya memiliki maksud berpergian yang tinggi, tiga orang yang memiliki maksud berpergian sedang, dan dua orang yang memiliki maksud berpergian rendah.

Tabel 1. Jumlah dan presentase maksud berpergian responden

\begin{tabular}{lcc}
\hline Maksud Berpergian & Jumlah (orang) & Presentase (\%) \\
\hline Rendah & 19 & 25.33 \\
Sedang & 47 & 62.67 \\
Tinggi & 9 & 12.00 \\
\hline Total & 75 & 100.0 \\
\hline
\end{tabular}

Sumber: Hasil olahan data peneliti (2019) 
Keterdedahan Media Komunikasi

Sebanyak 97\% responden memiliki keterdedahan media komunikasi yang rendah, sedangkan keterdedahan responden dengan nilai sedang dan tinggi masingmasing sebanyak 1.50 persen. Responden yang terdedah dengan media komunikasi yang berisi informasi mengenai pariwisata di Kabupaten Pesawaran yaitu sebanyak 29 orang di mana media yang sering mereka dapatkan untuk memperoleh informasi pariwisata Pesawaran adalah internet sebanyak 20 orang, disusul dengan televisi sebanyak 17 orang, yang terakhir adalah radio yang hanya didapatkan oleh satu orang, hal tersebut dapat dilihat pada Gambar 3.

Hasil menunjukkan bahwa sebagian besar responden menggunakan internet sebagai media pencarian informasi mengenai pariwisata di Kabupaten Pesawaran. Responden juga mengaku bahwa media yang sering digunakan untuk mencari informasi mengenai pariwisata adalah internet. Dinas Pariwisata dan Kebudayaan Pesawaran memiliki website resmi yang berisikan informasi daerah pariwisata, kesenian dan kebudayaan, serta kuliner Kabupaten Pesawaran. Namun, berdasarkan penelitian Nirwana dan Saleh (2012) khalayak masih belum terpuaskan dengan informasi yang disajikan oleh website resmi Dinas Pariwisata dan Kebudayaan Pesawaran karena informasi yang disajikan tidak lengkap seperti informasi fasilitas obyek pariwisata, dan informasinya tidak diperbaharui. Selain itu, pihak Dinas Pariwisata dan Kebudayaan Pesawaran bekerjasama dengan pemegang akun media sosial di twitter dan instagram, seperti akun twitter @infopesawaran dan @jelajahpesawaran. Media sosial ini merupakan media baru yang memberikan kesempatan bagi yang terlibat dalam sektor pariwisata dalam rangka untuk mendekati wisatawan dengan cara yang paling efektif, hal tersebut dapat mengurangi biaya iklan produk pariwisata (Bizirgianni \& Dionysopoulou 2013). 


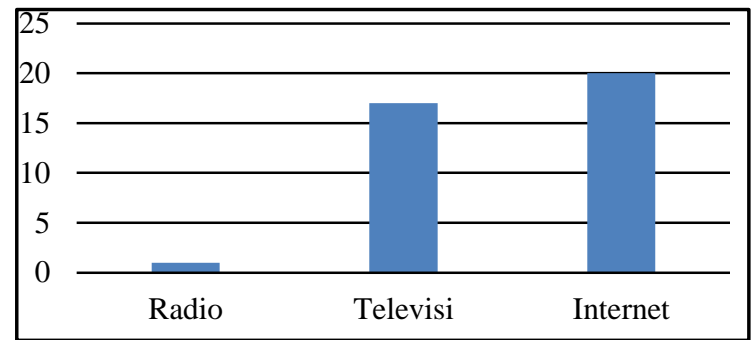

Gambar 3. Penggunaan media komunikasi tentang pariwisata di Kabupaten Pesawaran

Sumber: Hasil olahan data peneliti (2019)

Selain internet, responden terdedah informasi mengenai pariwisata Pesawaran dengan media Televisi. Televisi merupakan salah satu media yang sering mempromosikan pariwisata Pesawaran. Dinas Pariwisata dan Kebudayaan Pesawaran memang mengadakan kerjasama dengan salah satu stasiun televisi swasta sejak tahun 2014. Semenjak itu, pariwisata Pesawaran selalu menghiasi layar televisi. Pada Gambar 3 menunjukkan bahwa sebagian besar responden tersebut merupakan pengguna aktif internet. Media sosial merupakan salah satu situs yang sering diakses mahasiswa, seluruh mahasiswa mengaku merupakan pengguna media sosial. Beberapa responden menyebutkan bahwa selain digunakan untuk bersosialisasi dan berkomunikasi dengan teman, media sosial juga digunakan untuk media pencarian informasi dan hiburan. Berikut penggunaan media sosial responden disajikan pada Tabel 2.

Tabel 2. Jumlah dan presentase penggunaan media sosial

\begin{tabular}{lcc}
\hline Penggunaan Media Sosial & Jumlah (orang) & Presentase (\%) \\
\hline Sangat Rendah & 51 & 68.00 \\
Rendah & 11 & 14.67 \\
Tinggi & 6 & 8.00 \\
Sangat Tinggi & 7 & 9.33 \\
\hline Total & 75 & 100.00 \\
\hline
\end{tabular}

Sumber: Hasil olahan data peneliti (2019) 
Hasil tersebut menunjukkan bahwa mayoritas responden menggunakan media sosial sangat rendah yaitu sebanyak 68.00 persen, diikuti dengan penggunaan media sosial yang rendah sebanyak 14.67 persen, tinggi sebanyak 8.00 persen, dan sangat tinggi yaitu 9.33 persen. Hal itu berarti bahwa pengguna aktif media sosial hanya sebagian kecil saja. Media sosial yang paling banyak digunakan yaitu youtube, diikuti facebook, dan yang paling sedikit digunakan yaitu twitter. Berbeda dengan hasil penelitian Bizirgianni dan Dionysopoulou (2013) yang menyebutkan bahwa 99\% wisatawan muda mempunyai akun facebook, dan media sosial youtube, twitter, myspace, flickr merupakan media sosial sampingannya. Selain media sosial youtube, facebook, twitter responden juga menggunakan media sosial lainnya untuk mengakses informasi, seperti instagram, line, path. Penggunaan media sosial ini berbeda tergantung karakteristik khusus mereka (Bizirgianni \& Dionysopoulou ,2013). Setelah melihat penggunaan media sosial pada kalangan mahasiswa, sebaiknya promosi mengenai pariwisata untuk kalangan usia muda menggunakan media sosial yang paling banyak digunakan oleh mereka seperti youtube dan facebook.

\section{Pengetahuan Awal Responden}

Pengetahuan awal responden diukur sebelum responden mendapat perlakuan melalui media video mengenai pariwisata di Kabupaten Pesawaran. Hasil menunjukkan secara umum pengetahuan awal responden masih rendah yaitu memperoleh skor rata-rata 9.92 dari skor terendah nol dan skor tertinggi 28. Skor ini diukur sebelum responden melihat video mengenai pariwisata Pesawaran, sehingga dalam kondisi ini responden belum mempunyai pengetahuan tentang daya tarik pariwisata di Kabupaten Pesawaran. Hasil skor rata-rata pengetahuan awal responden berdasarkan kelompok perlakuan disajikan sebagai pada Tabel 3 berikut ini. 
Tabel 3. Skor rata-rata pengetahuan awal responden berdasarkan kelompok perlakuan

\begin{tabular}{lc}
\hline \multicolumn{1}{c}{ Kelompok Perlakuan } & Rata-rata Skor Pretest \\
\hline Foto-Gaya Bahasa Resmi & 9.47 \\
Foto-Gaya Bahasa & 5.78 \\
Percakapan & \\
Infografis-Gaya Bahasa & 13.27 \\
Resmi & \\
Infografis-Gaya Bahasa & 12.93 \\
Percakapan & \\
Kontrol & 8.13 \\
\hline
\end{tabular}

Sumber: Hasil olahan data peneliti (2019)

Tabel 3 menunjukkan bahwa rata-rata skor paling kecil di antara kelompok perlakuan yaitu pada kelompok perlakuan dengan kombinasi foto dan gaya bahasa percakapan (FP) sebesar 5.78, kemudian perlakuan dengan kombinasi foto dan gaya bahasa resmi (FR) sebesar 9.47, kombinasi infografis dan gaya bahasa percakapan (IP) yaitu sebesar 12.93, dan paling tinggi nilai-rata-rata pengetahuan awal responden yaitu pada kelompok dengan kombinasi perlakuan infografis dan gaya bahasa resmi (IR) sebesar 13.27. Kelompok kontrol sendiri mempunyai skor rataan pengetahuan awal sebesar 8.13.

Tabel 4. Hasil sidik ragam satu arah terhadap pengetahuan awal responden

\begin{tabular}{lccccc}
\hline \multicolumn{1}{c}{ Sumber Keragaman } & $\mathrm{JK}$ & $\mathrm{db}$ & $\mathrm{KT}$ & Fhitung & Sig \\
\hline Antar Kelompok & 609.787 & 4 & 152.447 & 2.331 & 0.064 \\
Dalam Kelompok & 4577.733 & 70 & 65.396 & & \\
\hline Total & 5187.520 & 74 & & & \\
& & & & & \\
\hline
\end{tabular}

Sumber: Hasil olahan data peneliti (2019)

Keterangan : JK=jumlah kuadrat, $\mathrm{db}=$ derajat bebas, $\mathrm{KT}=$ kuadrat tengah, $\alpha \leq 0.05$ 
Tabel 4 menunjukkan hasil sidik ragam satu arah terhadap nilai rata-rata pengetahuan awal responden pada kelima kelompok tidak berbeda nyata dengan signifikansi ((sig. 2-tailed) $\mathrm{p}>0.05)$. Hal tersebut berarti bahwa pengetahuan responden tentang pariwisata di Kabupaten Pesawaran tidak berbeda antara satu kelompok dengan kelompok lainnya. Hal ini dapat disimpulkan bahwa responden memiliki pengetahuan yang relatif sama atau homogen tentang pariwisata di Kabupaten Pesawaran sebelum diberi perlakuan. Hasil tersebut menunjukkan bahwa rata-rata responden belum mengetahui tentang pariwisata di daerah Kabupaten Pesawaran, seperti sejarah dan budaya, pariwisata agama, pariwisata hasil pertanian, kerajinan, dan kuliner khas daerah tersebut. Hasil di atas memberikan penyadaran bagi pemasar pariwisata bahwa daerah Pesawaran ini belum banyak diketahui oleh khayalak luas terutama oleh wisatawan muda.

Pengetahuan Akhir Responden

Hasil posttest didapatkan skor rata-rata 28.9 dari skor terendah yaitu 2 (dua) dan skor tertinggi yaitu 39. Adapun hasil rata-rata skor posttest dari setiap kelompok perlakuan dapat dilihat pada Tabel 5.

Tabel 5. Skor rata-rata pengetahuan akhir responden

\begin{tabular}{lc}
\hline \multicolumn{1}{c}{ Kelompok Perlakuan } & Rata-rata Skor Posttest \\
\hline Foto-Gaya Bahasa Resmi (FR) & 34.73 \\
Foto-Gaya Bahasa Percakapan & 27.93 \\
$(\mathrm{FP})$ & \\
Infografis-Gaya Bahasa Resmi & 36.53 \\
(IR) & \\
Infografis-Gaya Bahasa & 37.53 \\
Percakapan (IP) & \\
Kontrol & 7.93
\end{tabular}

Sumber: Hasil olahan data peneliti (2019) 
Hasil pada Tabel 5 tersebut menunjukkan bahwa nilai rata-rata pengetahuan akhir kelompok perlakuan yang paling rendah berasal dari kelompok dengan kombinasi foto dan gaya bahasa resmi (FR) yaitu sebesar 27.93, diikuti oleh kelompok dengan kombinasi foto dan gaya bahasa percakapan (FP) yaitu sebesar 34.73, kemudian kelompok kombinasi infografis dan gaya bahasa resmi (IR) yaitu sebesar 36.53, dan yang paling tinggi adalah kelompok dengan kombinasi infografis dan gaya bahasa percakapan (IP) yaitu sebesar 37.53. Secara keseluruhan hasil posttest menunjukkan adanya peningkatan pengetahuan mahasiswa tentang pariwisata di Kabupaten Pesawaran dimana tingkat pengetahuan mahasiswa sebelumnya termasuk pada kategori rendah, sementara pada posttest diperoleh hasil tingkat pengetahuan mahasiswa masuk pada kategori tinggi.

Hasil analisis menunjukkan bahwa mahasiswa mampu menyerap informasi mengenai pariwisata di daerah Pesawaran yang diperoleh dari media video. Hal tersebut juga diperkuat dengan adanya perbedan yang signifikan antara kelompok kontrol dan kelompok perlakuan dimana skor rata-rata pengetahuan akhir responden pada kelompok kontrol adalah 7.93 .

Peningkatan Pengetahuan Responden

Analisa terhadap pesan yang disampaikan melalui media video tentang pariwisata di Kabupaten Pesawaran dilakukan untuk mengetahui efektivitas penyampaian pesan tersebut. Efektivitas penyampaian pesan yang terdapat pada media video dapat dilihat dari hasil peningkatan pengetahuan responden. Peningkatan pengetahuan responden dapat didapatkan melalui selisih skor pretest dan posttest. Adapun hasil selisih skor pretest dan posttest dapat dilihat dalam tabel 6 berikut ini: 
Tabel 6. Selisih skor pretest dan posttest berdasarkan kelompok pengetahuan responden

\begin{tabular}{cccc}
\hline Kelompok Perlakuan & \multicolumn{2}{c}{ Skor } \\
& Pretest & Posttest & Selisih \\
\hline Foto-Gaya Bahasa Resmi (FR) & $9.47^{*}$ & $34.73^{*}$ & $25.26^{\mathrm{a}}$ \\
Foto-Gaya Bahasa Percakapan (FP) & $5.8^{*}$ & $27.93^{*}$ & $22.15^{\mathrm{a}}$ \\
Infografis-Gaya Bahasa Resmi (IR) & $13.27^{*}$ & $36.53^{*}$ & $23.27^{\mathrm{a}}$ \\
Infografis-Gaya Bahasa Percakapan & $12.93^{*}$ & $37.53^{*}$ & $24.60^{\mathrm{a}}$ \\
(IP) & & & \\
Kontrol & $8.13^{\text {tn }}$ & $7.93^{\text {tn }}$ & $-0.2^{\mathrm{b}}$ \\
\hline
\end{tabular}

Sumber: Hasil olahan data peneliti (2019)

Keterangan: ${ }^{*}$ berhubungan nyata pada $\mathrm{p}<0.05 ;{ }^{* *}$ berhuhungan sangat nyata pada $\mathrm{p}<0.01$; tn $=$ berhubungan tidak nyata

Skor rata-rata responden pada saat pretest lebih rendah dibandingkan dengan posttest. Hal tersebut dapat dilihat pada Tabel 6. Pengetahuan awal responden (pretest) dari rata-rata skor kelompok perlakuan yaitu 10.36, sedangkan skor ratarata pengetahuan akhir responden (posttest) yaitu 34.18. Peningkatan pengetahuan ini cukup tinggi dikarenakan banyak responden yang belum mengetahui pariwisata di daerah Pesawaran. Dari pernyataan yang diberikan mahasiswa melalui kuesioner pretest, sebagian besar mahasiswa belum mengetahui pariwisata sejarah dan budaya Pesawaran, pariwisata pertanian Pesawaran, pariwisata kerajinan dan kuliner Pesawaran. Pada hasil pretest tersebut mahasiswa hanya mengetahui beberapa hal yang sudah sangat terkenal dari daerah Pesawaran seperti makanan khas Pesawaran, bahkan diantara mereka ada yang sama sekali tidak mengetahui tentang pariwisata di Kabupaten Pesawaran, hal itu terbukti dengan hasil jawabannya yang sama sekali tidak ada yang benar. 
Selain kelompok perlakuan, penelitian ini juga menganalisa peningkatan pengetahuan pada responden yang tergabung dalam kelompok kontrol yaitu kelompok yang tidak mendapatkan perlakuan khusus seperti kelompok perlakuan. Tabel 6 menunjukkan skor rata-rata pengetahuan awal responden pada kelompok kontrol masuk ke dalam kategori rendah yaitu sebesar 8.13, sedangkan pada skor rata-rata pengetahuan akhir yaitu 7.93 dengan rata-rata selisihnya -0.2. Hal tersebut menunjukkan bahwa tidak terjadi peningkatan pengetahuan pada kelompok kontrol, bahkan rata-rata tersebut menunjukkan bahwa terdapat kemunduran pengetahuan responden. Hasil selisih skor pengetahuan menunjukkan terdapat enam responden yang mengalami kemunduran dalam pengetahuan, satu orang selisih pengetahuan antara pretest dan posttest stagnan, dan sisanya mengalami peningkatan pengetahuan. Namun, peningkatan pengetahuan pada kelompok kontrol ini tidak meningkat secara signifikan, yaitu rata-rata skor peningkatannya sebesar 2.43. Jadi, peningkatan pengetahuan mahasiswa hanya terjadi dikarenakan pengaruh media video tentang pariwisata di Kabupaten Pesawaran.

Perbedaan peningkatan pengetahuan responden setelah menonton video tentang pariwisata di Kabupaten Pesawaran diuji menggunakan uji $t$. Hasil uji $t$ tersebut menunjukkan terdapat perbedaan nyata antara antara skor rata-rata pretest dengan posttest pada kelompok yang diberi perlakuan dengan signifikansi $(\mathrm{p} \leq 0.05)$, sedangkan pada kelompok kontrol tidak berbeda nyata $(\mathrm{p}>0.05)$. Berdasarkan hasil tersebut, maka hipotesis penelitian yang pertama pada penelitian ini diterima. Hal ini terlihat dari adanya perbedaan tingkat pengetahuan yang signifikan pada responden sebelum dan sesudah menonton video tentang pariwisata di Kabupaten Pesawaran, yang bahwa penyajian visual (foto dan infografis) serta gaya bahasa (resmi dan percakapan) mampu meningkatkan pengetahuan responden tentang pariwisata tersebut. 
Pada Tabel 6 menunjukkan bahwa seluruh kombinasi perlakuan berpengaruh nyata terhadap peningkatan pengetahuan. Berdasarkan hasil uji Duncan didapatkan bahwa kelompok yang diberi perlakuan berbeda nyata dengan kelompok kontrol, namun perlakuan FP (foto-gaya bahasa percakapan) tidak berbeda nyata dengan IR (infografis-gaya bahasa resmi), IP (infografis-gaya bahasa percakapan), dan FR (fotogaya bahasa resmi). Berdasarkan hasil tersebut, maka hipotesis yang kedua pada penelitian ini ditolak. Artinya, peningkatan pengetahuan responden mengenai pariwisata di Kabupaten Pesawaran dapat dipengaruhi oleh penggunaan video, baik itu menggunakan penyajian visual foto atau infografis dengan gaya bahasa resmi ataupun percakapan. Informasi yang disampaikan pada setiap video sama, yang berbeda hanya jenis visual dan gaya bahasanya saja. Jadi, secara konten semua informasi yang disampaikan dari setiap video adalah sama. Hasil statistik menunjukkan bahwa informasi yang disampaikan melalui video, sama-sama dapat menyampaikan informasi yang diinginkan dengan jelas. Selama informasi yang disampaikan dari setiap video itu jelas dan mudah dimengerti, maka informasi tersebut akan mudah tersampaikan kepada responden. Penggunaan video dengan narasi merupakan alat bantu yang sangat berguna dalam menyampaikan informasi dan dapat meningkatkan pengetahuan.

\section{Simpulan Dan Saran}

\section{Simpulan}

Dari hasil penelitian menggunakan metode True Experimental dengan desain faktorial 2x2 dan menggunakan Pretest Posttest Control Group Desain dapat disimpulkan sebagai berikut:

1. Penyajian visual dan gaya bahasa melalui video dapat mempengaruhi peningkatan pengetahuan mahasiswa tentang pariwisata di KabupatenPesawaran.

2. Seluruh kombinasi penyajian visual dan gaya bahasa berpengaruh terhadap peningkatan pengetahuan. Peningkatan pengetahuan responden mengenai 
pariwisata di Kabupaten Pesawaran dapat dipengaruhi oleh penggunaan video, baik itu menggunakan penyajian visual foto atau infografis dengan gaya bahasa resmi ataupun percakapan.

\section{Saran}

1. Pihak pemasar pariwisata perlu menggunakan media video untuk memasarkan dan memberikan pengetahuan tentang pariwisata di suatu daerah terutama pariwisata sejarah dan budaya agar menumbuhkan rasa cinta tanah air dan melestarikan budaya Indonesia.

2. Dapat diteliti lebih lanjut, penggunaan video yang penyajian visualnya menggabungkan foto ke dalam infografis karena bentuk penyajian tersebut saling melengkapi.

3. Penggunaan video untuk mempromosikan pariwisata ini dapat disebarkan melalui media sosial yang tidak memungut biaya yang besar dalam penyebarannya, misalnya youtube untuk calon wisatawan usia muda.

\section{Daftar Pustaka}

[Bappenas]. Badan Perencanaan Pembangunan Nasional. 2010. Lampiran Peraturan Presiden RI Nomor 5 Tahun 2010 tentang Rencana Pembangunan Jangka Mengengah Nasional [internet]. [diunduh 2014 Des28]. Tersedia di: http://ristek.go.id/file/2010/rpjmbapenas/buku-ii-bab-iii.pdf.

Bizirgianni I, Dionysopoulou P. 2013. The influence of tourist trends of youth tourism through social media $(\mathrm{sm})$ \& information and communication technologies (icts). Social and Behavior Science.

Campbell DT, Stanley JC. 1996. Experimental and Quasi-Experimental Designs for Research. Chicago (US): Rand McNally College.

Chamdani U. 2008. Aspek komunikasi dalam pengembangan agrowisata. Jurnal Kepariwisataan Indonesia.

Chung N, Koo C. 2014. The use of social media in travel information search. Telematics and Informatics. 
[Disparbud] Dinas Pariwisata dan Kebudayaan Kabupaten Pesawaran. 2015.

Rekapitulasi Data Pengunjung Obyek Wisata Kabupaten Pesawaran 2013. Pesawaran (ID): Disparbud Kabupaten Pesawaran.

Gustina, Anna. 2013. Pengaruh media audio visual terhadap peningkatan pengetahuan petani kakao di kabupaten Lampung Timur, Laporan Penelitian, Unila.

Kamlongera C, Mefalopulos P. 2014. Participatory Communication Strategy Design. Rome (IT): FAO. 2nd Ed.

Nirwana TP, Saleh A. 2012. Peran promosi pariwisata terhadap perilaku wisatawan. Jurnal Sains Komunikasi dan Pengembangan Masyarakat.

Nurfathiyah TP, Suratno T. 2011. Pengaruh visualisasi gerak dan foto pada media video terhadap peningkatan pengetahuan petani di Desa Tangkit Baru. Jurnal Penelitian Seri Sains.

\section{Profil Penulis}

Anna Gustina Zainal merupakan dosen Program Studi Ilmu Komunikasi Fisip Universitas Lampung. Bidang yang ditekuni beliau mencakup media sosial dan media informasi serta komunikasi. Beliau pernah menjabat sebagai Ketua program Studi Diploma III Hubungan Masyarakat di Universitas Lampung. 